\title{
Thierry Poyet, Bouvard et Pécuchet. Le savoir et la sagesse
}

Ida Merello

\section{Q OpenEdition}

1 Journals

\section{Edizione digitale}

URL: https://journals.openedition.org/studifrancesi/3169

DOI: 10.4000/studifrancesi.3169

ISSN: 2421-5856

\section{Editore}

Rosenberg \& Sellier

\section{Edizione cartacea}

Data di pubblicazione: 1 juillet 2013

Paginazione: 479

ISSN: 0039-2944

\section{Notizia bibliografica digitale}

Ida Merello, «Thierry Poyet, Bouvard et Pécuchet. Le savoir et la sagesse», Studi Francesi [Online], 170 (LVII | II) | 2013, online dal 30 novembre 2015, consultato il 02 février 2023. URL: http:// journals.openedition.org/studifrancesi/3169; DOI: https://doi.org/10.4000/studifrancesi.3169

Questo documento è stato generato automaticamente il 2 février 2023.

\section{(c) (i) $\odot$}

Creative Commons - Attribuzione - Non commerciale - Non opere derivate 4.0 Internazionale - CC BYNC-ND 4.0

https://creativecommons.org/licenses/by-nc-nd/4.0/ 


\title{
Thierry Poyet, Bouvard et Pécuchet. Le savoir et la sagesse
}

\author{
Ida Merello
}

\section{NOTIZIA}

THIERRY POYET, Bouvard et Pécuchet. Le savoir et la sagesse, Paris, Kimé, 2012, pp. 208.

L'A. ha il pregio di affrontare il romanzo di Flaubert in maniera integrale, dal doppio punto di vista letterario e filosofico, supportando ogni riflessione con un'attenta lettura delle dichiarazioni dello scrittore nella Correspondance, e inglobando così, in un saggio unitario, molti aspetti che sono stati trattati separatamente. Dal punto di vista letterario, ribadisce nella soluzione finale di Bouvard e Pécuchet (la trascrizione del sapere dei libri - vale a dire l'elenco delle loro sciocchezze -) la rappresentazione della messa sotto scacco della scrittura romanzesca, destinata a implodere sotto il peso dei materiali. Dal punto di vista filosofico, invece, l'A. si interroga sulla concezione del sapere di Flaubert: da un lato, è inteso come esperienza individuale e quasi sensoriale; dall'altro invece è visto solo come ammasso di pregiudizi di cui non salvare nulla. Se l'argomento centrale sono dunque le ragioni dell'opera, e le riflessioni dello scrittore sul proprio work in progress, coniugate ai dubbi sulla recezione del romanzo da parte del pubblico, l'A. ripropone altresì un'analisi dei personaggi, con un confronto con Homais che va a tutto vantaggio dei due impiegati, e con Charles Bovary, di cui sono messi in luce gli aspetti positivi. 